\title{
Gambaran histopatologik lambung tikus Wistar (Rattus norvegicus) yang diberikan air perasan jeruk nipis (Citrus aurantifolia)
}

\author{
${ }^{1}$ Suhaidir Laomo \\ ${ }^{2}$ Lily L. Loho \\ ${ }^{2}$ Carla F. Kairupan
}

\author{
${ }^{1}$ Kandidat Skripsi Fakultas Kedokteran Universitas Sam Ratulangi Manado \\ ${ }^{2}$ Bagian Patologi Anatomi Fakultas Kedokteran Universitas Sam Ratulangi Manado \\ Email: suha.laomo@gmail.com
}

\begin{abstract}
Lime squash is often used as a herbal remedy for gastritis, even though it is acidic. It contains citric acid and vitamin $\mathrm{C}$ which in certain doses can be irritant to the stomach. Nevertheless, lime squash also contains antioxidants such as limonene, flavonoids, and vitamin $\mathrm{C}$, that play certain roles in improving the protection of the stomach and the ability of cell regeneration, and as anti-inflammatory agents. This study aimed to reveal the histopathological features of the gaster of Wistar rats (Rattus norvegicus) treated with lime squash. This was an experimental laboratory study using 15 adult Wistar rats divided into three groups (five rats in each group). Group A (negative control) was given no treatment; group B and C were treated with lime squash 0.5 and $1.56 \mathrm{ml} /$ day, respectively. Lime squash was given in a single dose for seven consecutive days. Rats were terminated on day eight. The results revealed that the gaster of Wistar rats in group A were similar to that of the normal gaster, while group B and C showed no signs of inflammation and the gastric gland cells appeared enlarged and dense. Conclusion: Histopathological features of the gaster of Wistar rats, treated with either low or high dose (three-fold) lime squash, showed no signs of abnormalities such as inflammation, however, there were enlarged glandular cells which might be related to increased gastric mucosal defence.
\end{abstract}

Keywords: lime, gastric histopathological features, inflammatory cells, gastric glands

\begin{abstract}
Abstrak: Air perasan jeruk nipis sering digunakan sebagai obat herbal terhadap gastritis, meskipun bersifat asam. Air perasan jeruk nipis mengandung asam sitrat yang pada dosis tertentu menjadi bahan iritan terhadap lambung. Namun demikian, kandungan antioksidan seperti limonene, flavonoid dan vitamin $\mathrm{C}$ berperan dalam meningkatkan proteksi lambung dan kemampuan regenerasi sel, serta sebagai anti inflamasi. Penelitian ini bertujuan untuk mengetahui gambaran histopatologik lambung tikus wistar yang diberikan air perasan jeruk nipis. Jenis penelitian ialah eksperimental menggunakan 15 ekor tikus Wistar yang dibagi dalam tiga kelompok (lima ekor tikus tiap kelompok). Kelompok A (kontrol negatif) tidak diberi perlakuan; kelompok $\mathrm{B}$ dan $\mathrm{C}$ masing-masing diberi air perasan jeruk nipis $0,5 \mathrm{ml} / \mathrm{hari}$ dan 1,56 ml/hari dosis tunggal selama tujuh hari, Semua tikus diterminasi pada hari ke- 8 . Hasil yang didapatkan pada gambaran histopatologik lambung tikus wistar yaitu: kelompok A sesuai dengan gambaran lambung normal; kelompok B dan C tidak menunjukkan tanda-tanda peradangan namun sel-sel kelenjar lambung tampak membesar dan padat. Simpulan: Gambaran histopatologik lambung tikus wistar yang diberi air perasan jeruk nipis, baik dosis rendah maupun tinggi (tiga kali lipat) tidak menunjukkan tanda-tanda kelainan seperti peradangan, melainkan tampak terjadi pembesaran sel-sel kelenjar lambung yang mungkin berhubungan dengan peningkatan pertahanan mukosa lambung.
\end{abstract}

Kata kunci: jeruk nipis, gambaran histopatologik lambung, sel radang, kelenjar lambung 
Makanan atau minuman yang bersifat asam tidak dianjurkan pada pasien gastirits karena akan memperberat keluhan. ${ }^{1}$ Namun demikian, akhir-akhir ini jeruk nipis (Gambar 1) sering digunakan masyarakat Indonesia sebagai obat untuk menyembuhkan penyakit lambung (gastritis) meskipun sifatnya asam.

Berdasarkan pengalaman empiris, mengonsumsi air perasan jeruk nipis dapat menyebabkan gejala gastritis namun terdapat sebagian masyarakat yang mengonsumsi rutin air perasan jeruk nipis tanpa adanya keluhan yang terkait dengan gangguan lambung. Bahkan, jeruk nipis digunakan oleh sebagian orang untuk mengatasi keluhan yang timbul akibat iritasi lambung.

Air perasan jeruk nipis yang mengandung asam sitrat pada dosis tertentu dapat menjadi bahan iritan terhadap lambung. Walaupun demikian, air perasan jeruk nipis ternyata mengandung antioksidan seperti flavonoid dan limonene yang berperan dalam meningkatkan proteksi lambung, sebagai anti inflamasi, dan mengandung vitamin $\mathrm{C}$ yang berperan dalam regenerasi sel. ${ }^{2-4}$ Untuk mengetahui mengapa konsumsi air perasan jeruk nipis memperlihatkan reaksi yang berbeda-beda, maka dilakukan penelitian terhadap gambaran histopatologik lambung tikus wikus wistar yang diberi air perasan jeruk nipis.

\section{METODE PENELITIAN}

Penelitian eksperimental dengan desain post test only pada kelompok perlakuan ini dilakukan pada bulan Oktober sampai Desember 2016 di Laboratorium Patologi Anatomi Fakultas Kedokteran Universitas Sam Ratulangi Manado. Subjek penelitian yang digunakan yaitu 15 ekor tikus wistar (Rattus norvegicus) dewasa yang dibagi dalam tiga kelompok (lima ekor tikus/ kelompok). Kelompok A merupakan kontrol negatif, kelompok B (perlakuan I) diberikan air perasan jeruk nipis sebanyak 0,5 $\mathrm{ml} /$ hari, dan kelompok C (perlakuan II) diberikan air perasan jeruk nipis sebanyak $1,56 \mathrm{ml} / \mathrm{hari}$. Air perasan jeruk nipis diberikan dalam dosis tunggal selama tujuh hari berturut-turut. Dosis air perasan jeruk nipis didasarkan pada pengalaman empiris dalam mengurangi keluhan terkait gangguan lambung, yaitu air perasan dari satu sampai tiga buah jeruk nipis/hari.Semua tikus diterminasi pada hari kedelapan. Hasil pemrosesan jaringan lambung tikus wistar kemudian diamati di bawah mikroskop.

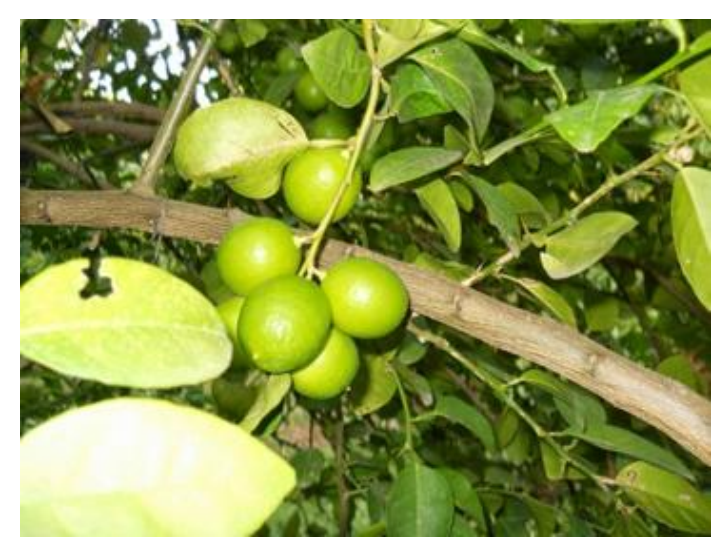

Gambar 1. Jeruk Nipis (Citrus aurantifolia)

\section{HASIL PENELITIAN \\ Kelompok A (kontrol negatif)}

Gambaran mikroskopik lambung tikus wistar kelompok kontrol negatif sesuai dengan gambaran lambung normal. Terlihat lapisan mukosa, lapisan submukosa, lapisan muskularis, dan lapisan serosa yang utuh dengan sedikit sel-sel radang (dalam batas normal) pada lapisan mukosa (Gambar 2).

\section{Kelompok B (perlakuan I)}

Pada gambaran mikroskopik lambung tikus wistar, empat dari lima preparat tampak baik dan tidak ada tanda-tanda radang. Sel-sel pada kelenjar lambung terlihat membesar dan lebih padat dibandingkan kelompok kontrol (Gambar 3). Pada satu preparat tampak sedikit selsel radang terutama PMN tersebar pada lapisan mukosa, submukosa, dan muskularis serta adanya mikroerosi pada lapisan mukosa (Gambar 4).

\section{Kelompok C (kelompok perlakuan II)}

Pada tikus wistar kelompok $\mathrm{C}$ 
diperoleh gambaran histopatologik lambung tikus wistar yang tampak baik dan tidak ada tanda-tanda radang.Sel-sel pada kelenjar lambung terlihat membesar dan lebih padat dibandingkan kelompok kontrol (Gambar 5).

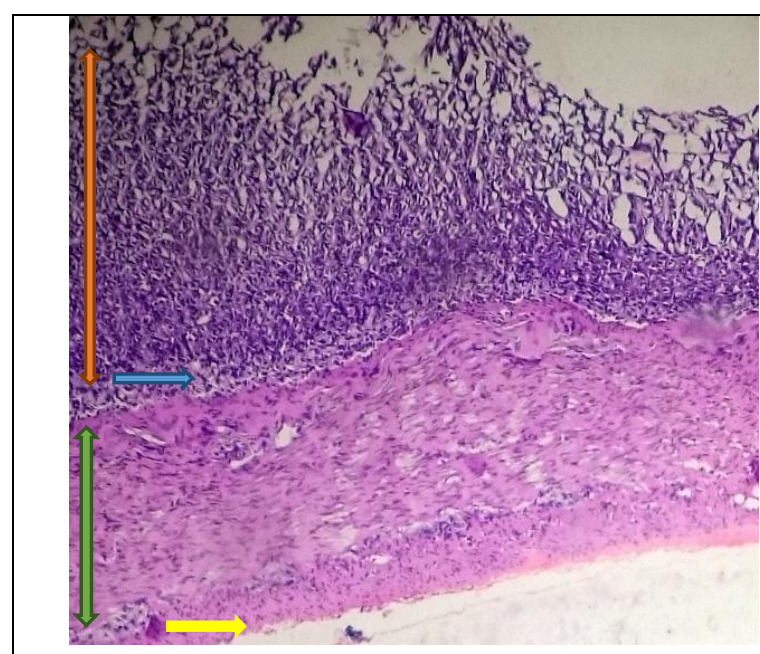

Gambar 2.Gambaran mikroskopik lambung tikus Wistar kelompok A. Terlihat lapisan mukosa (panah jingga), lapisan submukosa (panah biru), lapisan muskularis (panah hijau), dan lapisan serosa (panah kuning) sesuai dengan lambung normal. Pembesaran $10 \times 10$.

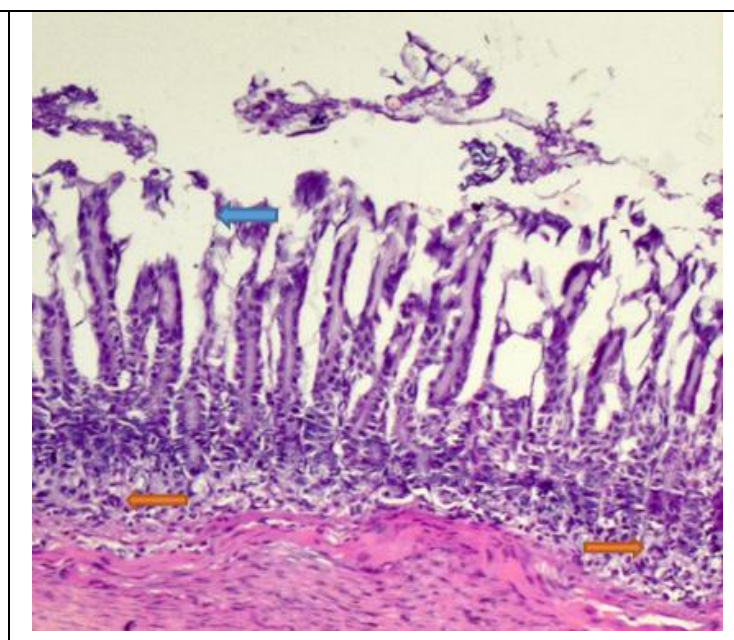

Gambar 4. Gambaran mikroskopik kelompok B (preparat nomor 5). Mikroerosi (panah biru) dan sel-sel PMN (panah jingga). Pembesaran 10×10.

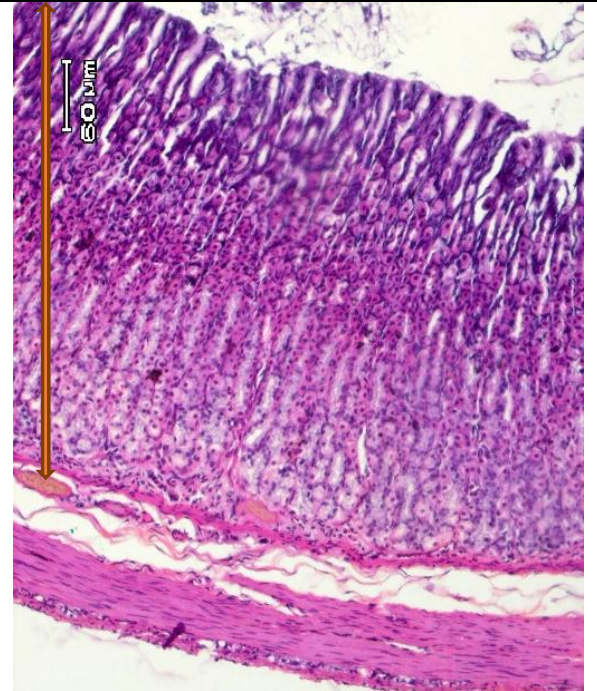

Gambar 3. Gambaran mikroskopik lambung tikus Wistar kKelompok B. Kelenjar lambung (panah jingga). Pembesaran $10 \times 10$.

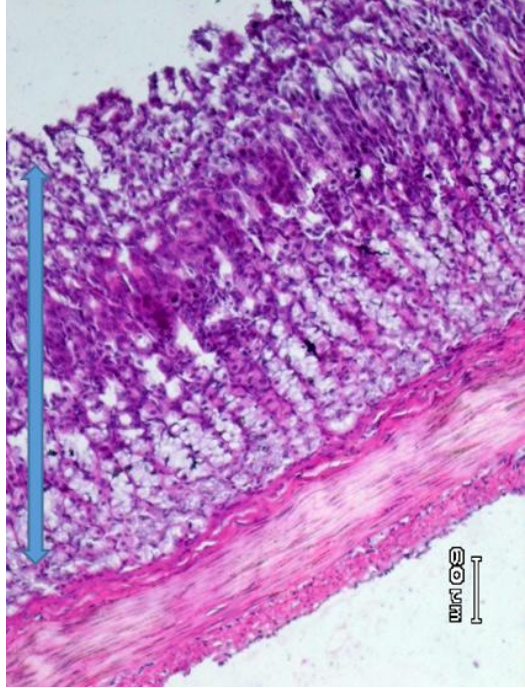

Gambar 5. Gambaran mikroskopik lambung tikus Wistar Kelompok C kelenjar lambung (panah biru). pembesaran $10 \times 10$.

\section{BAHASAN}

Lambung sebagai organ pencernaan memiliki fungsi mengatur, menyimpan, dan mencerna makanan yang masuk. ${ }^{5}$ Hal ini membuat lambung rentan terhadap makanan dan minuman yang mengandung mikroorganisme berbahaya maupun bahan iritan. ${ }^{6,7}$ Dosis tertentu asam sitrat dan vitamin $\mathrm{C}$ yang terkandung dalam air perasan jeruk nipis dapat menjadi bahan 
iritan terhadap lambung. ${ }^{8}$ Selain itu, reaksi alergi terhadap air perasan jeruk nipis dan intoleransi terhadap asam sitrat mungkin menjadi penyebab iritasi dan timbulnya sensasi nyeri pada lambung. ${ }^{6}$ Namun demikian, air perasan jeruk nipis dipercaya dapat melindungi lambung dari bahan iritan penyebab gastritis karena bahan antioksidan yang dikandungnya. ${ }^{9}$

Air perasan jeruk nipis, meskipun mengandung asam sitrat, tidak memberikan pengaruh yang besar pada gambaran mikroskopik lambung seperti terlihat pada penelitian ini(kelompok B dan $\mathrm{C}$ ). Asam sitrat dengan rumus molekul $\left(\mathrm{C}_{6} \mathrm{H}_{8} \mathrm{O}_{7}\right)$ dan berat molekul 192,123 $\mathrm{g} /$ molmerupakan asam alami yang ditemukan dalam jumlah besar pada buah-buahan, terutama jeruk, lemon, dan jeruk nipis. ${ }^{10}$ Asam sitrat merupakan asam yang relatif lemah dan aman dikonsumsi. Namun demikian, pada jumlah yang besar dan konsumsi berlebih, $\mathrm{pH}$ asam sitrat akan menurun. Asam sitrat konsentrasi $1 \mathrm{mmol} / \mathrm{L}$ memiliki $\mathrm{pH}$ sebesar 3,24; $10 \mathrm{mmol} / \mathrm{L} \mathrm{pH}$ sebesar 2,62; dan pada konsentrasi $100 \mathrm{mmol} / \mathrm{L} \mathrm{pH}$ turun menjadi 2,08. Air perasan jeruk nipis mengandung asam sitrat sebanyak $46 \mathrm{gr} / \mathrm{L}$. Konsumsi maksimal asam sitrat yaitu 0,1 gr/kgBB/hari. ${ }^{11,12}$ Berdasarkan pengalaman empiris, konsumsi air perasan jeruk nipis sebanyak 1 atau 3 buah jeruk nipis per hari dapat mempengaruhi lambung, baik memberikan efek nyeri lambung maupun melindungi lambung. Pada penelitian ini, ternyata dosis air perasan jeruk nipis sebanyak 0,5 ml/hari (kelompok B) dan 1,56 $\mathrm{ml} /$ hari (kelompok C), masing-masing mengandung asam sitrat sebanyak 0,023 gr dan 0,07 gr asam sitrat,tergolong aman dan tidak menimbulkan efek samping yang bermakna. ${ }^{13,14}$

Kelenjar lambung adalah unit sekretorik dasar dari lambung dan berisi berbagai komponen sel. Kelenjar dimulai dari gastric pit dan membuka ke lumen lambung. Pada bagian pit dari lambung mengandung sebagian besar sel-sel yang menyekresi mucus; isthmus dan neck cells yang tersusun atas sel parietal, mengeluarkan $\mathrm{HCl}$ dan faktor intrinsik, dan sangat eosinofilik; sel chief yang bertanggung jawab untuk sekresi pepsinogen terletak lebih dekat ke dasar kelenjar, tampak bergranula dan basofilik. ${ }^{15}$ Pada penelitian ini, jaringan lambung tikus Wistar kelompok B dan $\mathrm{C}$ menunjukkan sel-sel kelenjar lambung yang membesar dan padat. Diduga bahwa kandungan limonene yang terkandung dalam air perasan jeruk nipis memiliki efek melindungi lambung dan berperan dalam peningkatan mukus lambung. Hal ini sejalan dengan beberapa penelitian sebelumnya. Penelitian yang dilakukan oleh Moraes et al. $^{2}$ dengan menggunakan minyak esensial dari Citrus aurantium dan limonene monoterpene, berhasil memroteksi lambung dari induksi etanol absolut dan NSAID (non-steroidal anti-inflammatory drug) pada tikus dengan keberhasilan 99\%. Minyak esensial dan limonene tidak mengganggu sekresi $\mathrm{H}^{+}$, serum gastrin atau tingkat gluthatione (GSH) pada mukosa lambung. Efek gastroprotektif dari minyak esensial dan limonene terjadi akibat peningkatan produksi mukus lambung yang diinduksi oleh tingkat PGE2. ${ }^{2}$ Pada penelitian lain yang dilakukan oleh Polo et al. ${ }^{16}$ dengan menggunakan minyak esensial Citrus aurantium, didapatkan adanya hubungan pembesaran kelenjar lambung dan peningkatan produksi mukus lambung yang berperan meningkatkan pertahanan lambung.

Dalam air perasan jeruk nipis terkandung juga flavonoid. Flavonoid merupakan senyawa alami yang penting dengan kegiatan biologis beragam. Citrus flavonoid terdiri atas naringin, naringenin, nobelitin, narirutin, dan hesperidin. Pada jeruk nipis terdapat hesperidin dan naringin. Flavonoid ini berperan sebagai anti inflamasi dan antioksidan kuat. ${ }^{17}$ Pada penelitian yang dilakukan oleh Mota et al. ${ }^{17}$ dengan menggunakan hewan coba yang diinduksi bahan iritan dan menggunakan substansi flavonoid yang berbeda-beda menunjukkan adanya efek gastroprotektif yang terjadi dari setiap substansi flavonoid yang digunakan. Mekanisme dari beberapa substansi masih belum jelas, termasuk 
mekanisme dari flavonoid jeruk nipis, yaitu hesperidin dan naringin. Selain sebagai gastroprotekif, flavonoid juga bertindak dalam penyembuhan ulkus lambung. ${ }^{18}$ Selain flavonoid, air perasan jeruk nipis juga mengandung antioksidan lain seperti vitamin $\mathrm{C}$ atau asam askorbat. Vitamin $\mathrm{C}$ atau asam askorbat merupakan vitamin yang larut dalam air. Vitamin $\mathrm{C}$ diperlukan untuk biosintesis kolagen, L-karnitin, dan neurotransmitter tertentu. Kolagen merupakan komponen penting dari jaringan ikat yang berperan dalam penyembuhan luka. Namun demikian konsumsi vitamin $\mathrm{C}$ lebih dari $1000 \mathrm{mg} / \mathrm{hari}$ dapat meningkatkan asam lambung dan menyebabkan gastritis. ${ }^{8,19,20}$

Lambung tikus Wistar kelompok perlakuan (B dan C) pada penelitian ini tidak memperlihatkan adanya peradangan yang dapat terjadi akibat vitamin $\mathrm{C}$ yang terkandung dalam air perasan jeruk nipis. Kemungkinan besar, kandungan vitamin $\mathrm{C}$ dalam air perasan jeruk nipis tidak melebihi dosis konsumsi maksimal perhari sehingga efek antioksidan vitamin $\mathrm{C}$ lebih berperan dibanding efek iritannya. Satu tikus pada kelompok B ditemukanmengalami gastiritis akut yang ditandai adanya sel-sel radang PMN dan mikroerosi. Hal ini mungkin disebabkan tikus ini sebelumnya telah menderita gastritis.

Penelitian ini telah menunjukkan bahwa pada dosis rendah maupun tinggi, air perasan jeruk nipis tidak menyebabkan peradangan atau gastritis. Sebaliknya, air perasan jeruk nipis berperan dalam meningkatkan proteksi lambung. Namun demikian, penelitian ini masih memiliki beberapa kekurangan, salah satunya yaitu dibutuhkannya percobaan dengan menggunakan range dosis yang lebih luas sehingga dapat memberikan hasil yang lebih jelas dan bermakna.

\section{SIMPULAN}

Gambaran histopatologik lambung tikus wistar yang diberi air perasan jeruk nipis, baik dosis rendah maupun tinggi (tiga kali lipat) tidak menunjukkan tanda-tanda kelainan seperti peradangan, melainkan tampak terjadi pembesaran sel-sel kelenjar lambung yang berhubungan dengan peningkatan pertahanan mukosa lambung.

\section{DAFTAR PUSTAKA}

1. Ling LM. 2013. Lemon Juice - Acidic, Alkaline, or Both? [cited 24-08-2016]. Available from http://www.vitalitylink.com/articleholistic-health-2055-lemon-juiceacidic-alkaline-body-water.

2. Moraes TM, Kushima H, Moleiro FC, Santos RC, Rocha LR, Marques MO, et al. 2009. Effects of limonene and essential oil from Citrus aurantium on gastric mucosa. Chem Biol Interact. 2009 Agustus 14 [cited 2016 Oct 12]. Available from: https://www.ncbi.nlm.nih.gov/pubmed/ 19410566

3. Moohi Y, Mi WS, Ik YK, Won BK, Soon HK, Sang DL, et al. 1998. Gastroprotective flavone/flavanone compounds with therapeutic effect on inflammatory bowel disease. $1998 \mathrm{Feb}$ 5. [cited 2016 Oct 09]. Available from: https://www.google.ch/patents/WO199 8004541A1?cl=en\#backward-citations

4. CCRC Farmasi UGM. 2014. Jeruk nipis (Citrus aurantifolia). [cited 2016 Aug 30]. Available from: http://ccrc.farmasi.ugm.ac.id/?page_id= 183.

5. Guyton AC, Hall JE. Watson Buku Ajar Fisiologi Kedokteran (11th ed). Jakarta: EGC, 2007; p. 824-5 [cited 4-12-2016]. Available from http://www.livestrong.com/article/5224 92-can-oranges-make-your-stomachache/.

6. Jones L, Cash B. Gastritis. [cited 2016 Dec 11]. Available from https://www.niddk.nih.gov/healthinformation/digestive-diseases/gastritis.

7. What is citric acid sodium citrate? Everyday Heatlh, Inc. 2016 November 5 [cited 2016 Oct 12]. Available from: http://www.everydayhealth.com/drugs/ citric-acid-sodium-citrate\#basics

8. Herbie T. Kitab Tanaman Berkhasiat Obat (1st ed). Yogyakarta: Octopus Publishing House, 2015; p. 360.

9. Citric acid. PubChem. 2016. [cited 2016 Dec 18]. Available from: https://pubchem.ncbi.nlm.nih.gov/comp 
ound/citric_acid\#section=Top.

10. Young RO, Young SR. The $\mathrm{pH}$ miracle. Four Winds Nutrition: 2016. [cited 2016 Dec 14]. Available from http://www.webnat.com/articles/mucus about.asp.

11. Penniston KL, Nakada SY, Holmes RP, Assimos DG. Quantitative assessment of citric acid in lemon juice, lime juice, and commercially-available fruit juice products. National Institute of Health, 2008 Maret.

12. Ehrlich DS. Gastritis. University of Maryland Medical Centre. 2015. [cited 2016 Dec 18]. Available from: http://umm.edu/health/medical/altmed/ condition/gastritis.

13. Citric Acid. [cited 2016 Dec 18]. Available from:

https://examine.com/supplements/citric -acid/.

14. Takizawa P. Gastric gland. Histology @ yale. [cited 2016 Dec 18]. Available from: http://medcell.med.yale.edu/histology/g i_tract_lab/gastric_gland.php.

15. Polo CM, Moraes TM, Pellizzon $\mathrm{CH}$, Marques MO, Rocha LR, HirumaLima CA. 2012. Gastric ulcer in middle-aged rats: The healing effect of essential oil from Citrus aurantium L. (Rutaceae). Evidence-Based Complementary and Alternative Medicine.509451. 2012; 2012. Article ID

16. Alam MA, Subhan N, Rahman MM, Uddin SJ, Reza HM, Sarker SD. Effect of citrus flavonoids, naringin and naringenin, on metabolic syndrome and their mechanisms of action. Adv Nutr. 2014;5:404-17.

17. Mota KS, Dias GE, Pinto ME, Ferreira AL, Brito AR, Lima CA, et al. Flavonoids with gastroprotective activity. Molecules. 2009;14(3):9791012.

18. Sodium Citrate / Citric Acid. Wolters Kluwer Health. 2016 October 1 [cited 2016 Oct 12]. Available from: https://www.drugs.com/ppa/sodiumcitrate-citric-acid.html

19. Office of Dietary Supplements. Vitamin C. National Institute of Health. [cited 2016 Dec 19]. Available from: https://ods.od.nih.gov/factsheets/Vitami nC-HealthProfessional/. 